\title{
A comprehensive review of microRNA-related polymorphisms in gastric cancer
}

\author{
B.W. Han ${ }^{1 *}$, Z.H. Li ${ }^{1 *}$, S.F. Liu ${ }^{1}$, H.B. Han', S.J. Dong ${ }^{1}$, H.J. Zou ${ }^{2}$, \\ R.F. Sun ${ }^{2}$ and J. Jia ${ }^{3}$ \\ ${ }^{1}$ Secondary Department of General Surgery, \\ Luoyang Central Hospital Affiliated to Zhengzhou University, \\ Luoyang, Henan, China \\ ${ }^{2}$ Central Laboratory, Yunnan University of Chinese Traditional Medicine, \\ Kunming, Yunnan, China \\ ${ }^{3}$ Center for Molecular Medicine, Zhejiang Academy of Medical Sciences, \\ Hangzhou, Zhejiang, China \\ *These authors contributed equally to this study. \\ Corresponding authors: R.F. Sun / J. Jia \\ E-mail: 64366120@qq.com / ann_nance@sina.com.cn
}

Genet. Mol. Res. 15 (2): gmr. 15028289

Received December 16, 2016

Accepted February 11, 2016

Published July 15, 2016

DOI http://dx.doi.org/10.4238/gmr.15028289

\begin{abstract}
MicroRNAs (miRNAs) are a class of small non-coding RNA molecules of about 22 nucleotides in length. miRNAs are highly conserved in both plants and animals, and function as gene regulators by binding to the 3'-untranslated region of target mRNAs for cleavage and/ or translational repression. miRNA biogenesis, stability, and regulation of expression are strongly sequence dependent. Sequence variants, such as single nucleotide polymorphisms (SNPs) in pri-miRNA, pre-miRNA, promoter regions, or miRNA-target sites, can influence miRNA function, thereby contributing to the pathological features of human disease. In this review, we focus on miRNA-related SNPs in gastric cancer and comprehensively analyze some commonly studied SNPs.
\end{abstract}

Key words: MicroRNA; Polymorphism; Gastric cancer; Review 


\section{INTRODUCTION}

MicroRNAs (miRNAs) are a class of small non-coding RNA molecules of about 22 nucleotides in length. The first miRNA (lin-4) was discovered by Lee et al. (1993) who reported that lin-4 can control the timing of Caenorhabditis elegans larval development. Subsequently, more than 1000 miRNAs have been identified, which can regulate nearly $30 \%$ of human genes. miRNAs are first transcribed by RNA polymerase II in the nucleus, forming primary miRNAs (pri-miRNAs). pri-miRNAs are then cleaved into hairpin loops (70-100 nucleotides) of precursor structure (pre-miRNA) by the Drosha-DGCR8 complex (Lee et al., 2003). pre-miRNAs are transported to the cytoplasm by exportin 5/Ran GTP, where premiRNAs are cleaved by the RNase III enzyme Dicer, resulting in mature miRNAs (Lund and Dahlberg, 2006). miRNAs are highly conserved in both plants and animals, and they function as gene regulators by binding to the 3'-untranslated region (3'-UTR) of target mRNAs for cleavage and/or translational repression (Lee et al., 1993).

miRNA biogenesis, stability, and regulation of expression are strongly sequence dependent (Leshkowitz et al., 2013). Sequence variants, such as single nucleotide polymorphisms (SNPs) in pri-miRNA, pre-miRNA, promoter regions, or miRNA target sites, can influence miRNA function, thereby contributing to the pathological features of human disease (Sethupathy et al., 2007). Sethupathy et al. (2007) reported an SNP (rs5186) in the 3'-UTR of angiotensin II receptor type 1 (AGTRI), where the rs5186 C allele abrogates an existing miR-155 binding site and induces elevated expression of AGTR1, which is implicated in hypertension. In view of the potential roles of miRNA-related SNPs, large numbers of studies have been carried out to identify disease-associated miRNA polymorphisms. In this review, we focus on miRNA-related SNPs in gastric cancer and comprehensively analyze some commonly studied SNPs.

\section{MATERIAL AND METHODS}

\section{miRNA-related polymorphisms in gastric cancer}

He et al. (2005) provided the first evidence that miRNA-related polymorphisms can change the expression of miRNAs and their target genes, which may contribute to carcinogenesis. Subsequently, miRNA-related polymorphisms were regarded as a gold mine for molecular epidemiology and a large number of studies have been done to assess the association of genetic polymorphisms with cancer risk. In this study, we review miRNA-related polymorphisms and gastric cancer. We searched PubMed using the following terms: "miRNA", "polymorphism", and "gastric cancer" (last search update: April 2, 2015). From this search, 64 records were identified and, after reading the full text, 45 studies reporting the relationship of SNPs with gastric cancer risk were included in this study.

The overview of miRNA-related polymorphisms evaluated in gastric cancer is shown in Table 1. According to SNP location, four groups were formed: pri-miRNA, pre-miRNA, promoter of miRNA, and 3'-UTR of target transcript. Overall, these are involved in more than 100 miRNAs, including miR-146a, miR-196a2, and miR-499a/b/c. 
Table 1. Overview of microRNA-related polymorphisms evaluated in gastric cancer.

\begin{tabular}{|c|c|c|c|}
\hline \multirow{6}{*}{$\begin{array}{l}\text { SNP location } \\
\text { pri-miRNA } \\
\end{array}$} & miRNA & is number & References \\
\hline & $\begin{array}{lll}\mid \operatorname{let}-7 \mathrm{an}-1 \\
\end{array}$ & ris10739971 & (Xu et al, 2014a,c) \\
\hline & $\begin{array}{lll}\text { let-7a-2 } \\
\text { let7f-2 }\end{array}$ & $\begin{array}{lll}\mathrm{rs} 629367, \mathrm{rs} 1143770 \\
\mathrm{~s} 1727658\end{array}$ & (Xu et al, 2014a) \\
\hline & 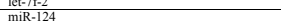 & 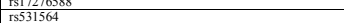 & (Zhou et al., 2012b; Xu et al., 2015) \\
\hline & 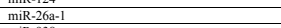 & 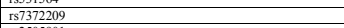 & (Zhou et al., 2012b; Stenhlolm et al., 2013; Xu et al., 2015) \\
\hline & miR-938 & rs 2505901 & (Arisawa et al., 2012) \\
\hline \multirow[t]{8}{*}{ 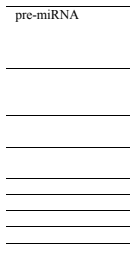 } & miR-146a & rs2910164 & 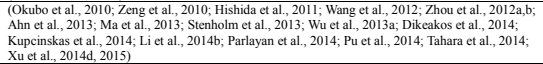 \\
\hline & miR-196a2 & rsil1614913 & 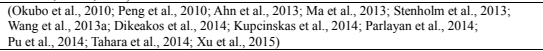 \\
\hline & miR-149 & ז $\mathrm{s} 2292832$ & $\begin{array}{l}\text { (Zhang tet al,., 2012; Ahn et al., 2013; Ma et al., 2013; Dikeakos et al., 2014; Pu et al., 2014; } \\
\text { Xu et al., 2015) }\end{array}$ \\
\hline & miR-499 & rs 3746444 & $\begin{array}{l}\text { (Okubo et al., 2010; Ahn et al., 2013; Ma et al., 2013; Pu et al., 2014; Tahara et al., 2014; } \\
\text { (O) }\end{array}$ \\
\hline & miR-27a & rs895819 & 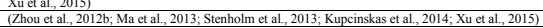 \\
\hline & miR-492 & $\mathrm{rs} 2289030$ & (Zhou et al., 2012b; Kupcinskas et al., 2014) \\
\hline & 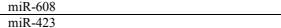 & 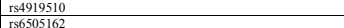 & 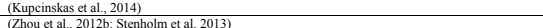 \\
\hline & \begin{tabular}{|l}
$\mathrm{min} R-423$ \\
$\mathrm{miR}-605$ \\
\end{tabular} & 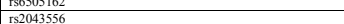 & (Zhou et al., 2012b; Stenholm et al, 2013) \\
\hline \multirow{2}{*}{$\overline{\text { Promoter of miRNA }}$} & \begin{tabular}{|lll}
$\mid m i k-003 / c$ \\
$m i R-34 b / c$
\end{tabular} & 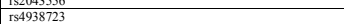 & (Znang et al, 2012) \\
\hline & 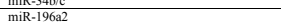 & $\frac{1549388123}{\mathrm{r} 335010275}$ & (Xung et al., 2014b) \\
\hline \multirow{38}{*}{$\begin{array}{l}\text { 3'-UTR of target } \\
\text { transcript }\end{array}$} & \begin{tabular}{|l}
$\operatorname{miR}-200 \mathrm{c}-3 \mathrm{p}$ \\
\end{tabular} & rsil2904 & (Li et al., 2014a) \\
\hline & \begin{tabular}{|l|l|l}
$\frac{\operatorname{miR}-498}{\operatorname{miR}-92 a-3 p}$ \\
\end{tabular} & 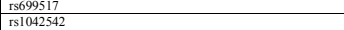 & \\
\hline & let-7 & 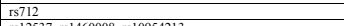 & (Li et al, 2013a) \\
\hline & \begin{tabular}{|l|l|l|l|l|l} 
miR-181a \\
miR-214, miR-3120, miR-199a-2
\end{tabular} & 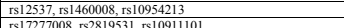 & (Lin et al., 2012) \\
\hline & miR-29c, miR-29b-2 & ז 1272724377, rs 14747442, rs 7523273 & \\
\hline & miR-215, miR-194-1 & rs 1124763, rs 17007135 & \\
\hline & miR-10b & rs 1348807, rs6736786 & \\
\hline & miR-375 & $\begin{array}{ll}\mathrm{rs} 452985, \mathrm{rs} 398926, \mathrm{rs} 359975 \\
\end{array}$ & \\
\hline & let-7g 9 & rs 1767, rs 7614727 & \\
\hline & miR-15b, miR-16-2 & $\begin{array}{ll}\mathrm{r} 5468050580, \text { rs } 10936201, \text { rs } 17236424 \\
\end{array}$ & \\
\hline & \begin{tabular}{|l|l|} 
miR-449a, miR-449b, miR-449c \\
mi. -466 mi
\end{tabular} & 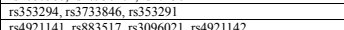 & \\
\hline & \begin{tabular}{|l|l|} 
miR-146a \\
miR-218
\end{tabular} & 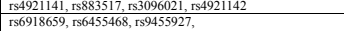 & \\
\hline & & 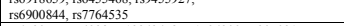 & \\
\hline & \begin{tabular}{|l}
$\operatorname{miR}-25$, miR-93, miR-106b \\
\end{tabular} & 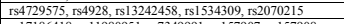 & \\
\hline & miR-29a, miR-29b-1 & 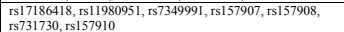 & \\
\hline & let-7f-1, let-7d & 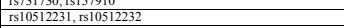 & \\
\hline & $\begin{array}{ll}\text { miR-23b, miR-27b, miR-3074, miR-24-1 } \\
\end{array}$ & $\begin{array}{l}\mathrm{rs} 10491560, \mathrm{rs} 10821447 \\
\end{array}$ & \\
\hline & $\frac{\mid \operatorname{miR}-107}{\operatorname{miR}-125-15}$ & 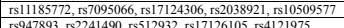 & \\
\hline & 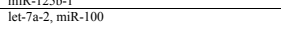 & 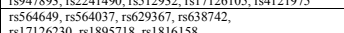 & \\
\hline & let-7i & 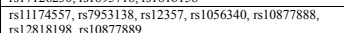 & \\
\hline & miR-16-1, miR-15a & 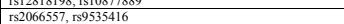 & \\
\hline & 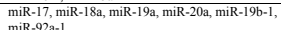 & rs 7322734, rs 17642969, rs 769040 & \\
\hline & 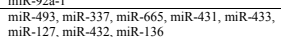 & rs 1077411, rs 6575805, rs3825569 & \\
\hline & 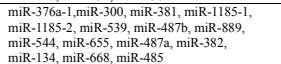 & 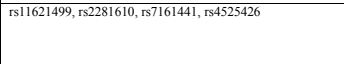 & \\
\hline & $\operatorname{miR}-132, \operatorname{miR}-212$ & 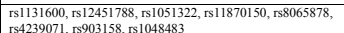 & \\
\hline & \begin{tabular}{|l|l|l|l|l|l|l} 
miR-10a \\
\end{tabular} & 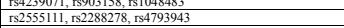 & \\
\hline & miR-301 & 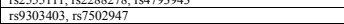 & \\
\hline & 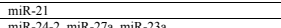 & 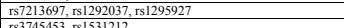 & \\
\hline & \begin{tabular}{|l|l|l} 
miR-24-2, miR-27a, miR-23a \\
miR-99b, let-7e, miR-125a
\end{tabular} & 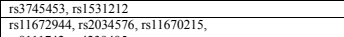 & \\
\hline & \begin{tabular}{|l|l|} 
miR-37la, miR-37lb, miR-372, miR-373 \\
\end{tabular} & 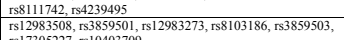 & \\
\hline & miR-296, miR-298 & \begin{tabular}{|l|l|} 
rs 17305227, rs 10403709 \\
rs $2282131, \mathrm{rs} 4815628$ \\
\end{tabular} & \\
\hline & & \begin{tabular}{|l|l|}
$\mathrm{r} s 17276117, \mathrm{rs} 17276124$ \\
\end{tabular} & \\
\hline & miR-125b-2 & rs $7279730, \mathrm{rs} 2823902$ & \\
\hline & miR-155 & rs 1893650 & \\
\hline & \begin{tabular}{|l|l} 
miR-30lb, miR-130b \\
\end{tabular} & rrs374659 & \\
\hline & let-7a-3, miR-4763, let-7b & 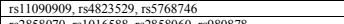 & \\
\hline & miR-221, miR-222 & \begin{tabular}{|l|l|}
$\mathrm{r} 22858070$, rs 1016588, r 22858060, rs 980878 \\
rs 1044165
\end{tabular} & \\
\hline & 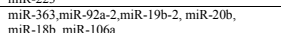 & \begin{tabular}{|l|l|} 
rs 916698, rs 17317628 \\
\end{tabular} & \\
\hline
\end{tabular}

\section{RESULTS AND DISCUSSION}

To date, the most commonly studied polymorphisms are rs2910164, rs11614913, rs2292832, and rs3746444, which are located in pre-miR-146a, pre-miR-196a2, pre-miR-149, and pre-miR-499, respectively. These polymorphisms were first reported by Hu et al. (2008), who found that rs11614913 might be used as prognostic biomarker for non-small cell lung cancer. Regarding the first report of the polymorphism in gastric cancer, Zeng et al. (2010) found that subjects with pre-miR-146a rs2910164 GC/GG genotypes had a 1.58-fold elevated risk of gastric cancer compared to carriers of the CC genotype [95\% confidence interval (CI) $=1.11-2.20 ; \mathrm{P}=0.009]$. For SNPs in pri-miRNA, Xu et al. (2014b) reported an rs629367 polymorphism located in pri-let-7a-2 and the CC genotype was associated with an increased risk 
of gastric cancer [odds ratio $(\mathrm{OR})=1.83 ; 95 \% \mathrm{CI}=1.00-3.32$ ] and poorer survival [hazard ratio $(\mathrm{HR})=4.48 ; 95 \% \mathrm{CI}=1.60-12.60]$. Arisawa et al. (2012) reported a polymorphism (rs2505901) in pri-miR-938 and the CC genotype was associated with a decreased risk of gastric cancer $(\mathrm{OR}=0.73 ; 95 \% \mathrm{CI}=0.55-0.99)$. Stenholm et al. (2013) reported that the variant allele of rs7372209 in pri-miR-26a1 was associated with a worse prognosis of advanced gastric cancer. In our previous study, we found that a polymorphism ( $\mathrm{rs} 4938723$ ) in the promoter of miR-34b/c was associated with a decreased risk of gastric cancer $(\mathrm{OR}=0.66 ; 95 \% \mathrm{CI}=0.45-0.97)(\mathrm{Pan}$ et al., 2015). Our result was confirmed by another study (Yang et al., 2014). Moreover, Xu et al. (2014a) reported a similarly decreased effect of rs35010275 in the promoter of miR-196a2 on gastric cancer (adjusted OR $=0.85 ; 95 \% \mathrm{CI}=0.77-0.94$ ). Besides SNPs in pri-miRNA, premiRNA, and promoters of miRNA, SNPs in the 3'-UTR of miRNA target genes have also been studied widely. For example, our other previous study showed that the rs 712 polymorphism in the 3'-UTR of let-7 was associated with an increased risk of gastric cancer (adjusted OR $=3.05$; $95 \% \mathrm{CI}=1.53-6.08)(\mathrm{Li}$ et al., 2013b). Li et al. (2014a) reported that the rs12904 polymorphism in the 3'-UTR of miR-200c was significantly associated with risk of gastric cancer $(\mathrm{OR}=0.65$; $95 \% \mathrm{CI}=0.50-0.85$ ), and the rs12904 A allele may abrogate miR-200c binding, inducing elevated levels of its target gene ephrin-A1. Lin et al. (2012) reported that the rs12537 CT/TT genotypes in the miR-181a binding site were associated with a significantly increased risk of gastric cancer (adjusted $\mathrm{OR}=1.72 ; 95 \% \mathrm{CI}=1.36-2.16)$ and poor overall survival $(\mathrm{HR}=1.38$; $95 \% \mathrm{CI}=1.03-1.83)$. Further analysis showed that the rs $12537 \mathrm{CT}$ genotype carriers had lower expression of the miR-181a target gene myotubularin-related protein 3.

Since gastric cancer is a complex disease with multiple factors involved, gene-gene and gene-environment analyses were also evaluated. Xu et al. (2014c) reported an increased interaction effect of the pri-let-7a-1 rs10739971 polymorphism with ERCC6 rs1917799 on gastric cancer $(\mathrm{OR}=2.59 ; 95 \% \mathrm{CI}=1.12-5.97)$. Zhang et al. $(2012)$ reported that smokers carrying pre-miR-149 rs2292832 CT/CC genotypes and pre-miR-605 rs2043556 AG/GG genotypes had an increased risk of gastric cancer $(\mathrm{OR}=1.87 ; 95 \% \mathrm{CI}=1.03-3.42)$, and tea drinkers with the pre-miR-149 rs2292832 CT/CC genotypes were protected from gastric cancer $(\mathrm{OR}=0.47 ; 95 \% \mathrm{CI}=0.29-0.77)$.

\section{Association of the pre-miR-146a rs2910164 polymorphism with risk of gastric cancer}

Over the past several years, the association of the pre-miR-146a rs2910164 polymorphism with risk of gastric cancer has been extensively investigated (Okubo et al., 2010; Zeng et al., 2010; Hishida et al., 2011; Wang et al., 2012; Zhou et al., 2012a,b; Ahn et al., 2013; Ma et al., 2013; Stenholm et al., 2013; Wu et al., 2013a; Dikeakos et al., 2014; Kupcinskas et al., 2014; Li et al., 2014b; Parlayan et al., 2014; Pu et al., 2014; Tahara et al., 2014; Xu et al., 2014d, 2015). In total, 18 studies were involved, including 10 case-control studies, 6 meta-analyses, and 2 case-only studies. As shown in Table 2, most of the studies were conducted in Asia, mainly in China, and only 3 studies were done in Europe. In case-control studies, some authors reported a positive result (Okubo et al., 2010; Zeng et al., 2010; Zhou et al., 2012a; Kupcinskas et al., 2014) and others reported a negative result (Hishida et al., 2011; Ahn et al., 2013; Dikeakos et al., 2014; Parlayan et al., 2014). To make the results more precise, some authors performed meta-analyses by combining all the data together (Ma et al., 
2013; Wu et al., 2013a; Li et al., 2014b; Xu et al., 2014d, 2015), which improved the statistical power. However, conflicting results were still present. For example, Li et al. (2013a) reported that the miR-146a rs2910164 polymorphism was significantly associated with a decreased risk of gastric cancer under the allele model $(\mathrm{OR}=0.87 ; 95 \% \mathrm{CI}=0.81-0.93)$ and recessive model $(\mathrm{OR}=0.81 ; 95 \% \mathrm{CI}=0.72-0.90) . \mathrm{Xu}$ et al. (2015) reported that the miR-146a rs 2910164 polymorphism was not associated with gastric cancer risk. Although it is difficult to decipher the exact reason for the inconsistent results, sample size, study design, and ethnicity should be considered. If the sample size is not large enough, the power is insufficient and false-negative results may occur. If the study design is hospital-based, selection bias cannot be ruled out and the results may be unreliable. Moreover, it is well known that genetic variants are diverse in different ethnicities. Therefore, further population-based association studies with large sample sizes are valuable to identify the real effect of the pre-miR-146a rs2910164 polymorphism on risk of gastric cancer.

Table 2. Association of the pre-miR-146a rs2910164 polymorphism with risk of gastric cancer.

\begin{tabular}{|c|c|c|c|c|c|c|c|c|c|c|c|c|}
\hline \multirow[t]{2}{*}{ First author } & \multirow[t]{2}{*}{ Publication year } & \multirow[t]{2}{*}{ Country (region) } & \multirow[t]{2}{*}{ Ethnicity } & \multirow[t]{2}{*}{ Study design } & \multirow[t]{2}{*}{ Case/control } & \multicolumn{2}{|c|}{ Case } & \multicolumn{2}{|c|}{ Control } & \multicolumn{2}{|c|}{ Results } & \\
\hline & & & & & & $\mathrm{CC}$ & $\mathrm{CG}$ & $\mathrm{GG}$ & $\mathrm{CC}$ & $\mathrm{CG}$ & GG & \\
\hline Zeng & 2010 & China (Nanjing) & Asian & \begin{tabular}{|l} 
Case-control \\
\end{tabular} & $304 / 304$ & 89 & 153 & 62 & 119 & 132 & 53 & \begin{tabular}{|l|} 
Association \\
\end{tabular} \\
\hline Okubo & 2010 & Japan (Toyoake) & Asian & \begin{tabular}{|l|} 
Case-control \\
\end{tabular} & $552 / 697$ & 236 & 243 & 73 & 322 & 254 & 121 & Association \\
\hline Hishida & 2011 & Japan (Nagoya) & Asian & \begin{tabular}{|l} 
Case-control \\
\end{tabular} & $583 / 1637$ & 230 & 271 & 82 & 633 & 775 & 229 & \begin{tabular}{|l|} 
No association \\
\end{tabular} \\
\hline Zhou & $2012 \mathrm{~b}$ & China (Hefei) & Asian & \begin{tabular}{|l|} 
Case-control \\
\end{tabular} & $331 / 336$ & & & & & & & \begin{tabular}{|l|} 
No association \\
\end{tabular} \\
\hline Zhou & $2012 \mathrm{a}$ & China (Yixing) & Asian & \begin{tabular}{|l|} 
Case-control \\
\end{tabular} & $1686 / 1895$ & 286 & 822 & 578 & 393 & 951 & 551 & Association \\
\hline Ahn & 2013 & South Korea (Seongnam) & \begin{tabular}{|l|l|l} 
Asian \\
\end{tabular} & \begin{tabular}{|l|} 
Case-control \\
\end{tabular} & $461 / 477$ & 159 & 231 & 71 & 164 & 221 & 62 & \begin{tabular}{|l|} 
No association \\
\end{tabular} \\
\hline Kupcinskas & 2014 & Lithuania (Kaunas) & \begin{tabular}{|l|} 
European \\
\end{tabular} & \begin{tabular}{|l|} 
Case-control \\
\end{tabular} & $363 / 351$ & 16 & 94 & 252 & 16 & 108 & 223 & Association \\
\hline Parlayan & 2014 & Japan (Tokyo) & \begin{tabular}{|l|l} 
Asian \\
\end{tabular} & \begin{tabular}{|l} 
Case-control \\
\end{tabular} & $160 / 524$ & & & & & & & \begin{tabular}{|l} 
No association \\
\end{tabular} \\
\hline Pu & $\frac{2014}{2014}$ & $\begin{array}{l}\text { Chipan (10Kyo) } \\
\text { China (Chengdu) }\end{array}$ & \begin{tabular}{|l|} 
Assian \\
Asian \\
\end{tabular} & \begin{tabular}{|l} 
Case-control \\
Case-control \\
\end{tabular} & $\frac{100 / 524}{197 / 513}$ & 65 & 96 & 36 & 143 & 274 & 96 & \begin{tabular}{|l} 
No asssoctatition \\
No assotion
\end{tabular} \\
\hline Dikeakos & 2014 & Greece (Athens) & \begin{tabular}{|l|} 
European \\
\end{tabular} & \begin{tabular}{|l|} 
Case-control \\
\end{tabular} & $163 / 480$ & 105 & 45 & 13 & 307 & 149 & 24 & \begin{tabular}{|l|} 
No association \\
\end{tabular} \\
\hline Stenholm & 2013 & Germany (Aachen) & \begin{tabular}{|l|} 
European \\
\end{tabular} & Case only & $487 /-$ & & & & 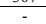 & & 2.1 & \begin{tabular}{|l|} 
No association \\
\end{tabular} \\
\hline Tahara & 2014 & Japan (Toyoake) & Asian & Case only & $130 \%$ & 67 & 47 & 16 & & & - & \begin{tabular}{|l|l|} 
No association \\
\end{tabular} \\
\hline Wang & 2012 & China (Jinan) & 200 & Meta-analysis & $1439 / 2688$ & 555 & 667 & 217 & 1074 & 1211 & 403 & \begin{tabular}{|l|} 
No association \\
\end{tabular} \\
\hline $\mathrm{Ma}$ & 2013 & China (Shanghai) & - & \begin{tabular}{|l} 
Meta-analysis \\
\end{tabular} & $3125 / 4533$ & 841 & 1489 & 795 & 1467 & 2112 & 954 & \begin{tabular}{|l} 
No association \\
\end{tabular} \\
\hline Wu & $2013 \mathrm{a}$ & China (Shangh & - & \begin{tabular}{|l} 
Meta-analysis \\
\end{tabular} & $1439 / 2638$ & 555 & 667 & 217 & 1074 & 1161 & 403 & $\begin{array}{l}\text { No association } \\
\end{array}$ \\
\hline $\mathrm{Li}$ & $2014 \mathrm{~b}$ & China (Hangzhou) & - & \begin{tabular}{|l} 
Meta-analysis \\
\end{tabular} & $3003 / 3343$ & 770 & 1449 & 784 & 998 & 1558 & 787 & \begin{tabular}{|l|} 
Association \\
\end{tabular} \\
\hline $\mathrm{Xu}$ & $2014 \mathrm{~d}$ & China (Guivang) & - & Meta-analysis & $4607 / 6736$ & 1293 & 2101 & 1213 & 2224 & 3079 & 1433 & \begin{tabular}{|l} 
No association \\
\end{tabular} \\
\hline $\mathrm{Xu}_{\mathrm{u}}$ & 2015 & China (Shenvang) & - & \begin{tabular}{|l} 
Meta-analysis \\
\end{tabular} & $4048 / 5876$ & 1212 & 1911 & 925 & 2065 & 2697 & 11114 & \begin{tabular}{|l|l|} 
No association \\
\end{tabular} \\
\hline
\end{tabular}

\section{Association of the pre-miR-196a2 rs11614913 polymorphism with risk of gastric cancer}

Overall, 13 studies reported the association between the pre-miR-196a2 rs11614913 polymorphism with risk of gastric cancer (Table 3) (Okubo et al., 2010; Peng et al., 2010; Ahn et al., 2013; Ma et al., 2013; Stenholm et al., 2013; Wang et al., 2013a,b; Dikeakos et al., 2014; Kupcinskas et al., 2014; Parlayan et al., 2014; Pu et al., 2014; Tahara et al., 2014; Xu et al., 2015). Among them, 8 were case-control studies, 3 were meta-analyses, and 2 were caseonly studies. Similar to the pre-miR-146a rs2910164 polymorphism, most of the studies were conducted in Asian populations (Okubo et al., 2010; Peng et al., 2010; Ahn et al., 2013; Wang et al., 2013b; Parlayan et al., 2014; Pu et al., 2014; Tahara et al., 2014). The phenomenon of conflicting results is also observed with this polymorphism, even in the same population. Peng et al. (2010) reported that the pre-miR-196a2 rs11614913 CC genotype was associated with a significantly increased risk of gastric cancer in a Chinese population $(\mathrm{OR}=1.57 ; 95 \% \mathrm{CI}=$ 1.03-2.39). However, Pu et al. (2014) did not find any significant difference between cases and controls in another Chinese population. Similarly, meta-analysis was used to assess whether the pre-miR-196a2 rs 11614913 polymorphism contributed to the risk of gastric cancer. No significant association was found between the pre-miR-196a2 rs11614913 polymorphism and gastric cancer risk by 3 independent groups (Ma et al., 2013; Wang et al., 2013a; Xu et al., 
2015), suggesting that the pre-miR-196a2 rs11614913 polymorphism may not be a risk factor for the development of gastric cancer.

\begin{tabular}{|c|c|c|c|c|c|c|c|c|c|c|c|c|}
\hline \multirow[t]{2}{*}{ First author } & \multirow{2}{*}{ Publication year } & \multirow[t]{2}{*}{ Country (region) } & \multirow{2}{*}{ Ethnicity } & \multirow{2}{*}{ Study design } & \multirow{2}{*}{ Case/control } & \multicolumn{3}{|c|}{ Case } & \multicolumn{3}{|c|}{ Control } & \multirow[t]{2}{*}{ Results } \\
\hline & & & & & & TT & CT & $\mathrm{CC}$ & TT & CT & $\mathrm{CC}$ & \\
\hline Peng & 2010 & \begin{tabular}{|l} 
China (Shenyang) \\
\end{tabular} & Asian & \begin{tabular}{|l|} 
Case-control \\
\end{tabular} & $213 / 213$ & 43 & 94 & 76 & 50 & 107 & 56 & \begin{tabular}{|l} 
Association \\
\end{tabular} \\
\hline Okubo & 2010 & \begin{tabular}{|l|l|} 
Japan (Toyoake) \\
\end{tabular} & Asian & \begin{tabular}{|l|} 
Case-control \\
\end{tabular} & $552 / 697$ & 166 & 281 & 105 & 223 & 350 & 124 & No association \\
\hline Ahn & 2013 & South Korea (Seongnam) & Asian & \begin{tabular}{|l|} 
Case-control \\
\end{tabular} & $461 / 477$ & 119 & 242 & 100 & 128 & 232 & 87 & \begin{tabular}{|l|} 
No association \\
\end{tabular} \\
\hline Wang & $2013 \mathrm{~b}$ & China (Nanjing) & Asian & Case-control & $1689 / 1946$ & 519 & 851 & 319 & 524 & 940 & 482 & Association \\
\hline Kupcinskas & 2014 & \begin{tabular}{|l|} 
Lithuania (Kaunas) \\
\end{tabular} & European & \begin{tabular}{|l|} 
Case-control \\
\end{tabular} & $363 / 351$ & 35 & 184 & 144 & 46 & 145 & 159 & Association \\
\hline Parlayan & 2014 & \begin{tabular}{|l|} 
Japan (Tokyo) \\
\end{tabular} & Asian & \begin{tabular}{|l|} 
Case-control \\
\end{tabular} & $160 / 524$ & - & - & - & - & - & - & \begin{tabular}{|l|} 
Association \\
\end{tabular} \\
\hline $\mathrm{Pu}$ & 2014 & \begin{tabular}{|l|} 
China (Chengdu) \\
\end{tabular} & Asian & \begin{tabular}{|l|} 
Case-control \\
\end{tabular} & $159 / 511$ & 25 & 95 & 39 & 86 & 324 & 101 & No association \\
\hline Dikeakos & 2014 & Greece (Athens) & European & \begin{tabular}{|l|} 
Case-control \\
\end{tabular} & $163 / 480$ & 15 & 46 & 102 & 79 & 229 & 172 & \begin{tabular}{|l|} 
Association \\
\end{tabular} \\
\hline Stenholm & 2013 & Germany (Aachen) & European & Case only & $487 /-$ & - & - & - & - & - & - & Association \\
\hline Tahara & 2014 & Japan (Toyoake) & Asian & \begin{tabular}{|l|} 
Case only \\
\end{tabular} & $130 /-$ & 37 & 63 & 30 & - & - & - & No association \\
\hline Wang & $2013 \mathrm{a}$ & \begin{tabular}{|l} 
China (Hefei) \\
\end{tabular} & - & \begin{tabular}{|l|} 
Meta-analysis \\
\end{tabular} & $765 / 910$ & 209 & 375 & 181 & 273 & 457 & 180 & No association \\
\hline Ma & 2013 & China (Shanghai) & - & \begin{tabular}{|l} 
Meta-analysis \\
\end{tabular} & $765 / 910$ & 209 & 375 & 181 & 273 & 457 & 180 & No association \\
\hline $\mathrm{Xu}$ & 2015 & \begin{tabular}{|l} 
China (Shenyang) \\
\end{tabular} & - & Meta-analysis & $3078 / 3783$ & 862 & 1514 & 702 & 1004 & 1858 & 921 & No association \\
\hline
\end{tabular}

\section{Association of the pre-miR-149 rs2292832 polymorphism with risk of gastric cancer}

The association of the pre-miR-149 rs2292832 polymorphism with risk of gastric cancer is presented in Table 4. In total, 6 studies were performed, including 4 case-control studies and 2 meta-analyses (Zhang et al., 2012; Ahn et al., 2013; Ma et al., 2013; Dikeakos et al., 2014; Pu et al., 2014; Xu et al., 2015). Zhang et al. (2012) reported that male subjects with the pre-miR-149 rs2292832 CT genotype had a decreased susceptibility for gastric cancer in an Asian population $(\mathrm{OR}=0.58 ; 95 \% \mathrm{CI}=0.37-0.93)$. Duplicate studies did not find the positive result in another two Asian populations (Ahn et al., 2013; Pu et al., 2014). The null result was also observed in meta-analyses (Ma et al., 2013; Xu et al., 2015). Nevertheless, Dikeakos et al. (2014) reported that the pre-miR-149 rs2292832 polymorphism was associated with an increased risk of gastric cancer in a European population under a homozygote comparison $(\mathrm{OR}=2.29 ; 95 \% \mathrm{CI}=1.25-4.22)$, dominant genetic model $(\mathrm{OR}=1.47 ; 95 \% \mathrm{CI}=1.03-2.10)$, and recessive genetic model $(\mathrm{OR}=2.00 ; 95 \% \mathrm{CI}=1.12-3.57)$. Taken together, these findings indicate that the pre-miR-149 rs2292832 polymorphism may have different roles in diverse ethnicities with respect to gastric cancer risk.

Table 4. Association of the pre-miR-149 rs2292832 polymorphism with risk of gastric cancer.

\begin{tabular}{|c|c|c|c|c|c|c|c|c|c|c|c|c|}
\hline \multirow[t]{2}{*}{ First author } & \multirow[t]{2}{*}{ Publication year } & \multirow[t]{2}{*}{ Country (region) } & \multirow[t]{2}{*}{ Ethnicity } & \multirow[t]{2}{*}{ Study design } & \multirow[t]{2}{*}{ Case/control } & \multicolumn{3}{|c|}{ Case } & \multicolumn{3}{|c|}{ Control } & \multirow[t]{2}{*}{ Results } \\
\hline & & & & & & TT & CT & $\mathrm{CC}$ & TT & CT & $\mathrm{CC}$ & \\
\hline Zhang & 2012 & China (Hangzhou) & Asian & Case-control & $274 / 269$ & 132 & 101 & 41 & 114 & 120 & 35 & Association \\
\hline Ahn & 2013 & South Korea (Seongnam) & Asian & Case-control & $461 / 477$ & 241 & 176 & 44 & 220 & 187 & 40 & No association \\
\hline $\mathrm{Pu}$ & 2014 & China (Chengdu) & Asian & $\begin{array}{l}\text { Case-control } \\
\end{array}$ & $187 / 459$ & 134 & 31 & 22 & 308 & 103 & 48 & \begin{tabular}{|l|} 
No association \\
\end{tabular} \\
\hline Dikeakos & 2014 & Greece (Athens) & European & \begin{tabular}{|l} 
Case-control \\
\end{tabular} & $163 / 480$ & 69 & 73 & 21 & 249 & 198 & 33 & \begin{tabular}{|l|} 
Association \\
\end{tabular} \\
\hline $\mathrm{Ma}$ & 2013 & China (Shanghai) & & Meta-analysis & $274 / 269$ & 132 & 101 & 41 & 114 & 120 & 35 & No association \\
\hline $\mathrm{Li}$ & $2013 \mathrm{a}$ & China (Chongqing) & - & Meta-analysis & $735 / 716$ & 373 & 277 & 85 & 334 & 307 & 75 & \begin{tabular}{|l|} 
No association \\
\end{tabular} \\
\hline $\mathrm{Xu}$ & 2013 & China (Nanjing) & - & \begin{tabular}{|l} 
Meta-analysis \\
\end{tabular} & $735 / 716$ & 373 & 277 & 85 & 334 & 307 & 75 & \begin{tabular}{|l|} 
No association \\
\end{tabular} \\
\hline $\mathrm{Xu}$ & 2015 & China (Shenyang) & - & Meta-analysis & $898 / 1196$ & 442 & 350 & 106 & 583 & 505 & 108 & \begin{tabular}{|l|} 
No association \\
\end{tabular} \\
\hline
\end{tabular}

\section{Association of the pre-miR-499 rs3746444 polymorphism with risk of gastric cancer}

The association of the pre-miR-499 rs3746444 polymorphism with risk of gastric cancer is summarized in Table 5. In total, 7 studies were performed, including 4 case-control studies, 2 meta-analyses, and 1 case-only study (Okubo et al., 2010; Ahn et al., 2013; Ma et 
al., 2013; Wu et al., 2013b; Pu et al., 2014; Tahara et al., 2014; Xu et al., 2015). All the studies were performed in Asian populations. Tahara et al. (2014) reported that the pre-miR-499 rs3746444 polymorphism was associated with overall survival and progression-free survival among gastric cancer cases of neoadjuvant chemotherapy. Cox's regression model revealed that the pre-miR-499 rs3746444 A allele was a predictive factor for better overall survival (HR $=0.33 ; 95 \% \mathrm{CI}=0.18-0.75$ ), indicating that the pre-miR-499 $\mathrm{rs} 3746444$ polymorphism may be used as a biomarker for prognosis of advanced gastric cancer treated with chemotherapy (Tahara et al., 2014).

\begin{tabular}{|c|c|c|c|c|c|c|c|c|c|c|c|c|}
\hline \multirow[t]{2}{*}{ First author } & \multirow[t]{2}{*}{$\begin{array}{l}\text { Publication year } \\
\end{array}$} & \multirow[t]{2}{*}{ Country (region) } & \multirow[t]{2}{*}{ Ethnicity } & \multirow[t]{2}{*}{\begin{tabular}{|l} 
Study design \\
\end{tabular}} & \multirow[t]{2}{*}{ Case/control } & \multicolumn{3}{|c|}{ Case } & \multicolumn{3}{|c|}{ Control } & \multirow[t]{2}{*}{ Results } \\
\hline & & & & & & AA & $\mathrm{AG}$ & GG & AA & $\mathrm{AG}$ & GG & \\
\hline Okubo & 2010 & Japan (Toyoake) & Asian & Case-control & $552 / 697$ & 364 & 151 & 37 & 466 & 198 & 33 & No association \\
\hline Ahn & 2013 & South Korea (Seongnam) & Asian & Case-control & $461 / 477$ & 323 & 123 & 15 & 299 & 134 & 14 & No association \\
\hline Wu & $2013 \mathrm{~b}$ & China (Xuzhou) & Asian & Case-control & $200 / 211$ & 149 & 47 & 4 & 166 & 42 & 3 & No association \\
\hline $\mathrm{Pu}$ & 2014 & China (Chengdu) & Asian & Case-control & $196 / 504$ & 141 & 50 & 5 & 366 & 121 & 17 & No association \\
\hline Tahara & 2014 & Japan (Toyoake) & Asian & Case only & $130 /-$ & 81 & 38 & 11 & - & - & - & Association \\
\hline $\mathrm{Ma}$ & 2013 & China (Shanghai) & - & Meta-analysis & $552 / 697$ & 364 & 151 & 37 & 466 & 198 & 33 & No association \\
\hline $\mathrm{Li}$ & $2013 a$ & China (Chongqing) & - & Meta-analysis & $1013 / 1144$ & 687 & 274 & 52 & 765 & 332 & 47 & No association \\
\hline $\mathrm{Xu}$ & 2015 & China (Shenyang) & - & Meta-analysis & $1213 / 1355$ & 836 & 321 & 56 & 931 & 374 & 50 & No association \\
\hline
\end{tabular}

\section{Association of the pre-miR-27a rs895819 polymorphism with risk of gastric cancer}

It has been identified that miR-27a functions as an oncogene and is upregulated in gastric cancer, with higher expression resulting in significantly worse overall survival. Downregulation of miR-27a may inhibit proliferation of gastric cancer cells and drug resistance, indicating that miR-27a plays a key role in the carcinogenesis of gastric cancer. Sun et al. (2010) reported that a polymorphism (rs895819) within miR-27a might contribute to gastric cancer susceptibility by modulating the expression of miR-27a and its target gene zinc finger and BTB domain containing 10. Duplication studies in Asian populations found the same results (Zhou et al., 2012b). However, Kupcinskas et al. (2014) failed to find any association between the pre-miR-27a rs895819 polymorphism and risk of gastric cancer in a European population (Table 6). Since only one case-control study was performed in Europe, further investigations are warranted to confirm these results.

Table 6. Association of the pre-miR-27a rs 895819 polymorphism with risk of gastric cancer

\begin{tabular}{|c|c|c|c|c|c|c|c|c|c|c|c|c|}
\hline \multirow[t]{2}{*}{ First author } & \multirow[t]{2}{*}{ Publication year } & \multirow[t]{2}{*}{ Country (region) } & \multirow[t]{2}{*}{ Ethnicity } & \multirow[t]{2}{*}{ Study design } & \multirow[t]{2}{*}{ Case/control } & \multicolumn{3}{|c|}{ Case } & \multicolumn{3}{|c|}{ Control } & \multirow[t]{2}{*}{ Results } \\
\hline & & & & & & TT & CT & $\mathrm{CC}$ & TT & CT & $\mathrm{CC}$ & \\
\hline Sun & 2010 & China (Wuxi) & Asian & Case-control & $304 / 304$ & 115 & 135 & 54 & 145 & 119 & 40 & Association \\
\hline Zhou & $2012 \mathrm{~b}$ & China (Hefei) & Asian & Case-control & $295 / 413$ & 166 & 122 & 7 & 214 & 167 & 32 & Association \\
\hline Stenholm & 2013 & Germany (Aacher & European & Case only & $487 /-$ & - & - & - & - & - & - & Association \\
\hline Kupcinskas & 2014 & Lithuania (Kaunas) & European & Case-control & $363 / 351$ & 181 & 144 & 38 & 156 & 164 & 30 & No association \\
\hline Song & 2014 & China (Yantai) & Asian & Case-control & $278 / 278$ & 105 & 124 & 49 & 131 & 111 & 36 & Association \\
\hline Ma & 2013 & China (Shanghai) & - & Meta-analysis & $599 / 717$ & 281 & 257 & 61 & 359 & 286 & 72 & No association \\
\hline $\mathrm{Xu}$ & 2015 & China (Shenyang) & - & Meta-analysis & $761 / 1018$ & 366 & 328 & 67 & 528 & 396 & 94 & Association \\
\hline
\end{tabular}

In this study, we reviewed miRNA-related polymorphisms in gastric cancer. In total, 45 studies reported the relationship of SNPs with gastric cancer risk. Among them, the most frequently studied polymorphisms were rs2910164, rs11614913, rs2292832, rs3746444, and rs895819, which are located in pre-miR-146a, pre-miR-196a2, pre-miR-149, pre-miR-499, and pre-miR-27a, respectively. Except for pre-miR-146a rs2910164 and pre-miR-27a rs895819, the polymorphisms were not associated with risk of gastric cancer. Therefore, functional 
polymorphisms for epidemiological research are of great importance to identify susceptibility genes. Moreover, gene-gene and gene-environment analyses will provide more evidence for the better understanding of tumorigenesis in gastric cancer.

\section{Conflicts of interest}

The authors declare no conflict of interest.

\section{ACKNOWLEDGMENTS}

Research supported by grants from the National Natural Science Foundation of China (\#81560429), and the Applied Basic Research Project of Yunnan Province (\#201501UH00069).

\section{REFERENCES}

Ahn DH, Rah H, Choi YK, Jeon YJ, et al. (2013). Association of the miR-146aC $>$ G, miR-149T $>$ C, miR-196a2T $>$ C, and miR-499A $>$ G polymorphisms with gastric cancer risk and survival in the Korean population. Mol. Carcinog. 52 (Suppl 1): E39-E51. http://dx.doi.org/10.1002/mc.21962

Arisawa T, Tahara T, Shiroeda H, Matsue Y, et al. (2012). Genetic polymorphisms of IL17A and pri-microRNA-938, targeting IL17A 3'-UTR, influence susceptibility to gastric cancer. Hum. Immunol. 73: 747-752. http://dx.doi. org/10.1016/j.humimm.2012.04.011

Dikeakos P, Theodoropoulos G, Rizos S, Tzanakis N, et al. (2014). Association of the miR-146aC $>$ G, miR-149T $>$ C, and miR-196a2T $>$ C polymorphisms with gastric cancer risk and survival in the Greek population. Mol. Biol. Rep. 41: 1075-1080. http://dx.doi.org/10.1007/s11033-013-2953-0

He H, Jazdzewski K, Li W, Liyanarachchi S, et al. (2005). The role of microRNA genes in papillary thyroid carcinoma. Proc. Natl. Acad. Sci. USA 102: 19075-19080. http://dx.doi.org/10.1073/pnas.0509603102

Hishida A, Matsuo K, Goto Y, Naito M, et al. (2011). Combined effect of miR-146a rs2910164 G/C polymorphism and Toll-like receptor $4+3725 \mathrm{G} / \mathrm{C}$ polymorphism on the risk of severe gastric atrophy in Japanese. Dig. Dis. Sci. 56: 1131-1137. http://dx.doi.org/10.1007/s10620-010-1376-1

Hu Z, Chen J, Tian T, Zhou X, et al. (2008). Genetic variants of miRNA sequences and non-small cell lung cancer survival. J. Clin. Invest. 118: 2600-2608.

Kupcinskas J, Wex T, Link A, Leja M, et al. (2014). Gene polymorphisms of micrornas in Helicobacter pylori-induced high risk atrophic gastritis and gastric cancer. PLoS One 9: e87467. http://dx.doi.org/10.1371/journal.pone.0087467

Lee RC, Feinbaum RL and Ambros V (1993). The C. elegans heterochronic gene lin-4 encodes small RNAs with antisense complementarity to lin-14. Cell 75: 843-854. http://dx.doi.org/10.1016/0092-8674(93)90529-Y

Lee Y, Ahn C, Han J, Choi H, et al. (2003). The nuclear RNase III Drosha initiates microRNA processing. Nature 425: 415-419. http://dx.doi.org/10.1038/nature01957

Leshkowitz D, Horn-Saban S, Parmet Y and Feldmesser E (2013). Differences in microRNA detection levels are technology and sequence dependent. RNA 19: 527-538. http://dx.doi.org/10.1261/rna.036475.112

Li L, Sheng Y, Lv L and Gao J (2013a). The association between two microRNA variants (miR-499, miR-149) and gastrointestinal cancer risk: a meta-analysis. PLoS One 8: e81967. http://dx.doi.org/10.1371/journal.pone.0081967

Li Y, Nie Y, Cao J, Tu S, et al. (2014a). G-A variant in miR-200c binding site of EFNA1 alters susceptibility to gastric cancer. Mol. Carcinog. 53: 219-229. http://dx.doi.org/10.1002/mc.21966

Li YJ, Zhang ZY, Mao YY, Jin MJ, et al. (2014b). A genetic variant in MiR-146a modifies digestive system cancer risk: a meta-analysis. Asian Pac. J. Cancer Prev. 15: 145-150. http://dx.doi.org/10.7314/APJCP.2014.15.1.145

Li ZH, Pan XM, Han BW, Guo XM, et al. (2013b). A let-7 binding site polymorphism rs712 in the KRAS 3' UTR is associated with an increased risk of gastric cancer. Tumour Biol. 34: 3159-3163. http://dx.doi.org/10.1007/s13277$\underline{013-0885-\mathrm{X}}$

Lin Y, Nie Y, Zhao J, Chen X, et al. (2012). Genetic polymorphism at miR-181a binding site contributes to gastric cancer susceptibility. Carcinogenesis 33: 2377-2383. http://dx.doi.org/10.1093/carcin/bgs292

Lund E and Dahlberg JE (2006). Substrate selectivity of exportin 5 and Dicer in the biogenesis of microRNAs. Cold Spring Harb. Symp. Quant. Biol. 71: 59-66. http://dx.doi.org/10.1101/sqb.2006.71.050 
Ma XP, Zhang T, Peng B, Yu L, et al. (2013). Association between microRNA polymorphisms and cancer risk based on the findings of 66 case-control studies. PLoS One 8: e79584. http://dx.doi.org/10.1371/journal.pone.0079584

Okubo M, Tahara T, Shibata T, Yamashita H, et al. (2010). Association between common genetic variants in premicroRNAs and gastric cancer risk in Japanese population. Helicobacter 15: 524-531. http://dx.doi.org/10.1111/ j.1523-5378.2010.00806.x

Pan XM, Sun RF, Li ZH, Guo XM, et al. (2015). Pri-miR-34b/c rs4938723 polymorphism is associated with a decreased risk of gastric cancer. Genet. Test. Mol. Biomarkers 19: 198-202. http://dx.doi.org/10.1089/gtmb.2014.0287

Parlayan C, Ikeda S, Sato N, Sawabe M, et al. (2014). Association analysis of single nucleotide polymorphisms in miR146a and miR-196a2 on the prevalence of cancer in elderly Japanese: a case-control study. Asian Pac. J. Cancer Prev. 15: 2101-2107. http://dx.doi.org/10.7314/APJCP.2014.15.5.2101

Peng S, Kuang Z, Sheng C, Zhang Y, et al. (2010). Association of microRNA-196a-2 gene polymorphism with gastric cancer risk in a Chinese population. Dig. Dis. Sci. 55: 2288-2293. http://dx.doi.org/10.1007/s10620-009-1007-x

$\mathrm{Pu}$ JY, Dong W, Zhang L, Liang WB, et al. (2014). No association between single nucleotide polymorphisms in premirnas and the risk of gastric cancer in Chinese population. Iran. J. Basic Med. Sci. 17: 128-133.

Sethupathy P, Borel C, Gagnebin M, Grant GR, et al. (2007). Human microRNA-155 on chromosome 21 differentially interacts with its polymorphic target in the AGTR1 3' untranslated region: a mechanism for functional singlenucleotide polymorphisms related to phenotypes. Am. J. Hum. Genet. 81: 405-413. http://dx.doi.org/10.1086/519979

Song B, Yan G, Hao H and Yang B (2014). rs 11671784 G/A and rs895819 A/G polymorphisms inversely affect gastric cancer susceptibility and miR-27a expression in a Chinese population. Med. Sci. Monit. 20: 2318-2326.

Stenholm L, Stoehlmacher-Williams J, Al-Batran SE, Heussen N, et al. (2013). Prognostic role of microRNA polymorphisms in advanced gastric cancer: a translational study of the Arbeitsgemeinschaft Internistische Onkologie (AIO). Ann. Oncol. 24: 2581-2588. http://dx.doi.org/10.1093/annonc/mdt330

Sun Q, Gu H, Zeng Y, Xia Y, et al. (2010). Hsa-mir-27a genetic variant contributes to gastric cancer susceptibility through affecting miR-27a and target gene expression. Cancer Sci. 101: 2241-2247. http://dx.doi.org/10.1111/j.13497006.2010.01667.x

Tahara T, Okubo M, Shibata T, Kawamura T, et al. (2014). Association between common genetic variants in premicroRNAs and prognosis of advanced gastric cancer treated with chemotherapy. Anticancer Res. 34: 5199-5204.

Wang F, Sun GP, Zou YF, Fan LL, et al. (2013a). Quantitative assessment of the association between miR-196a2 rs11614913 polymorphism and gastrointestinal cancer risk. Mol. Biol. Rep. 40: 109-116. http://dx.doi.org/10.1007/ $\underline{\text { s11033-012-2039-4 }}$

Wang J, Bi J, Liu X, Li K, et al. (2012). Has-miR-146a polymorphism (rs2910164) and cancer risk: a meta-analysis of 19 case-control studies. Mol. Biol. Rep. 39: 4571-4579. http://dx.doi.org/10.1007/s11033-011-1247-7

Wang S, Tao G, Wu D, Zhu H, et al. (2013b). A functional polymorphism in MIR196A2 is associated with risk and prognosis of gastric cancer. Mol. Carcinog. 52 (Suppl 1): E87-E95. http://dx.doi.org/10.1002/mc.22017

Wu D, Wang F, Dai WQ, He L, et al. (2013a). The miR-146a rs2910164 G > C polymorphism and susceptibility to digestive cancer in Chinese. Asian Pac. J. Cancer Prev. 14: 399-403. http://dx.doi.org/10.7314/APJCP.2013.14.1.399

Wu XJ, Mi YY, Yang H, Hu AK, et al. (2013b). Association of the hsa-mir-499 (rs3746444) polymorphisms with gastric cancer risk in the Chinese population. Onkologie 36: 573-576. http://dx.doi.org/10.1159/000355518

Xu L, Zhou X, Qiu MT, Yin R, et al. (2013). Lack of association between hsa-miR-149 rs2292832 polymorphism and cancer risk: a meta-analysis of 12 studies. PLoS One 8:e73762.

Xu M, Qiang F, Gao Y, Kang M, et al. (2014a). Evaluation of a novel functional single-nucleotide polymorphism (rs35010275 G>C) in MIR196A2 promoter region as a risk factor of gastric cancer in a Chinese population. Medicine 93: e173. http://dx.doi.org/10.1097/MD.0000000000000173

Xu Q, Dong Q, He C, Liu W, et al. (2014b). A new polymorphism biomarker rs629367 associated with increased risk and poor survival of gastric cancer in chinese by up-regulated miRNA-let-7a expression. PLoS One 9: e95249. http:// dx.doi.org/10.1371/journal.pone.0095249

Xu Q, Liu JW, He CY, Sun LP, et al. (2014c). The interaction effects of pri-let-7a-1 rs10739971 with PGC and ERCC6 gene polymorphisms in gastric cancer and atrophic gastritis. PLoS One 9: e89203. http://dx.doi.org/10.1371/journal. pone. 0089203

Xu Q, Liu JW and Yuan Y (2015). Comprehensive assessment of the association between miRNA polymorphisms and gastric cancer risk. Mutat. Res. Rev. Mutat. Res. 763: 148-160. http://dx.doi.org/10.1016/j.mrrev.2014.09.004

Xu Z, Zhang L, Cao H and Bai B (2014d). MiR-146a rs2910164 G/C polymorphism and gastric cancer susceptibility: a meta-analysis. BMC Med. Genet. 15: 117. http://dx.doi.org/10.1186/s12881-014-0117-2

Yang C, Ma X, Liu D, Wang Y, et al. (2014). Promoter polymorphisms of miR-34b/c are associated with risk of gastric cancer in a Chinese population. Tumour Biol. 35: 12545-12554. http://dx.doi.org/10.1007/s13277-014-2574-9 
Zeng Y, Sun QM, Liu NN, Dong GH, et al. (2010). Correlation between pre-miR-146a C/G polymorphism and gastric cancer risk in Chinese population. World J. Gastroenterol. 16: 3578-3583. http://dx.doi.org/10.3748/wjg.v16. $\underline{\mathrm{i} 28.3578}$

Zhang MW, Jin MJ, Yu YX, Zhang SC, et al. (2012). Associations of lifestyle-related factors, hsa-miR-149 and hsamiR-605 gene polymorphisms with gastrointestinal cancer risk. Mol. Carcinog. 51 (Suppl 1): E21-E31. http://dx.doi. org $/ 10.1002 / \mathrm{mc} .20863$

Zhou F, Zhu H, Luo D, Wang M, et al. (2012a). A functional polymorphism in Pre-miR-146a is associated with susceptibility to gastric cancer in a Chinese population. DNA Cell Biol. 31: 1290-1295. http://dx.doi.org/10.1089/ dna.2011.1596

Zhou Y, Du WD, Chen G, Ruan J, et al. (2012b). Association analysis of genetic variants in microRNA networks and gastric cancer risk in a Chinese Han population. J. Cancer Res. Clin. Oncol. 138: 939-945. http://dx.doi.org/10.1007/ $\underline{\mathrm{s} 00432-012-1164-8}$ 